\title{
Being inside out: the slippery slope between inclusion and exclusion in a Swiss educational project for unaccompanied refugee youth
}

\section{Annika Lems}

To cite this article: Annika Lems (2019): Being inside out: the slippery slope between inclusion and exclusion in a Swiss educational project for unaccompanied refugee youth, Journal of Ethnic and Migration Studies, DOI: 10.1080/1369183X.2019.1584702

To link to this article: https://doi.org/10.1080/1369183X.2019.1584702
(c) 2019 The Author(s). Published by Informa UK Limited, trading as Taylor \& Francis Group

\section{Published online: 20 Mar 2019.}

Submit your article to this journal $\pi$
LII Article views: 74

View Crossmark data $\nearrow$

Citing articles: 3 View citing articles $₫$ 


\title{
Being inside out: the slippery slope between inclusion and exclusion in a Swiss educational project for unaccompanied refugee youth
}

\author{
Annika Lems ${ }^{a, b}$

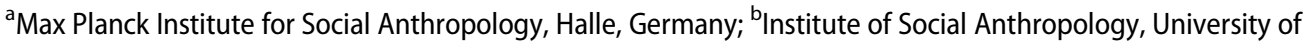 \\ Bern, Bern, Switzerland
}

\begin{abstract}
This article discusses how important social markers surrounding the figure of the unaccompanied minor, such as 'integration' and 'deservingness' are negotiated and made sense of by unaccompanied refugee youth and their teachers in a Swiss integration class. Starting from the premise of the classroom as both, a project of future-making and control, I investigate the ambiguous potential of education in creating and obstructing refugee youth's pathways into the larger society. By zooming in on the interactions between teachers and students in an educational project in Switzerland that was specifically designed to cater for the needs of unaccompanied refugee youth, I show how a project that is celebrated amongst practitioners as a best practice example for integration in fact creates an insurmountable number of new obstacles for the young people. I suggest that the ambiguous treatment of unaccompanied refugee youth as vulnerable victims in need of protection and integration on the one hand and as threats to the economic and cultural integrity of the Swiss 'national order of things' (Malkki, Liisa. 1995. "Refugees and Exile: From 'Refugee Studies' to the National Order of Things." Annual Review in Anthropology 24: 494-523) on the other, produces paradoxical dynamics whereby young people find themselves left outside whilst seemingly being 'in'.
\end{abstract}

\section{KEYWORDS}

Unaccompanied minors; refugee youth; refugee education; inclusion; exclusion; Switzerland; crisis

On a cold and wet winter afternoon in February $2016 \mathrm{I}$ had a conversation with Thierno, a seventeen years old teenager from Guinea. He had come to Switzerland as an asylum seeker one and a half years before and was still awaiting the decision on his case. We were on our way to a community house in the city of Bern where I caught up with a group of unaccompanied refugee youth every Tuesday afternoon as part of a collaborative radio project. As we entered the building, Thierno sighed. 'Life is hard', he said. 'Don't you think it's sometimes hard, and sometimes easy?' I asked. 'Yes that's true for others, but not for me. For me it is almost always hard', Thierno answered. I asked him to explain what was so hard for him at the moment. He made an expressive 
gesture with his arm. 'Oh, so many things, Annika!', he said. 'First of all I have to get used to this system, these people. I need to integrate here'. When I asked him to explain what 'integration' meant, he paused for a moment to think about it. Then he answered by giving me an example. He said that in Guinea you could start a conversation with anyone on the street, even if you did not know the person. 'In Switzerland you cannot even say hello', he said. He told me how, every time he had tried to talk to the Swiss students at the school where he attended the reception class for unaccompanied minors, they had reacted awkwardly or ignored him. 'I have learned that it is better to leave them alone', Thierno said. Becoming 'integrated', he explained, meant to learn not to take these things personally, but to understand them as part of normality. 'And my next problem is that I need to find a house because I am turning eighteen next month', Thierno continued, hinting at the fact that if he did not find a Swiss family that was willing to offer him a room in their private house, he would be moved from the home for unaccompanied minors where he had been living the past one and a half years into mass accommodation with adult asylum seekers as soon as he had reached the legal age of adulthood. 'And I need to become better at school to find an apprenticeship, and I don't even know whether I will be allowed to stay here or if I have to go somewhere else'. There was a moment of silence. 'You see, it is difficult', Thierno said, giving me a testing look. 'This life gives me so much stress'.

\section{Introduction}

This brief conversation snippet has much to say about the multifaceted quandaries unaccompanied refugee youth in Switzerland face. Struggling to make their way into a society that has found tacit ways of fending itself against 'outsiders', they constantly find themselves struggling to fulfil the benchmarks of a successful 'integration' while being held at an arm's length. This process of 'integrating', Thierno points out, is not about becoming an equal part of Swiss society. Rather, it is about being able to endure the pain of exclusion, of accepting it as part of a new normality. His struggle to work towards a more stable future by going to school and looking for work is undercut by a deep fear of turning eighteen and falling outside the protection net that is provided to unaccompanied minors. While the label 'minor' lends a certain degree of protection, this protection is tied to specific expectations and has a clear temporal limitation. Despite the special treatment including care, access to education and supervision Switzerland affords unaccompanied underage asylum seekers, for people like Thierno these 'child-friendly', inclusionary measures are often experienced as nothing more than a very brief reprieve from a life of extreme uncertainty.

What role do seemingly benign, well-intended efforts to ensure unaccompanied refugee youth's inclusion into host societies play when they are simultaneously confronted with a deep sense of ambiguity regarding their right to stay? How do the young people grapple with, make sense of and perhaps even contest these contradictory signals? And how do they carve out future pathways amidst a landscape of uncertainty and control? In this article I will address these questions by zooming in on an educational project in Switzerland that was specifically designed to cater for the needs of unaccompanied refugee youth. By examining the ways discourses about 'integration', 'crisis' and 'deservingness' trickle down into the everyday interactions between unaccompanied refugee youth and their 
Swiss teachers, I will show how a project that is celebrated amongst educational practitioners as a best practice example for integration in fact creates an insurmountable number of new obstacles for the young people. Paradoxically these integration classes, which, as the name implies, are aimed at including refugee youth into Swiss society, start from the premise of the need for separate educational streams in refugee-only classes. Sidelined and marked as problem cases, the young people find it difficult, if not impossible, to make the jump into mainstream educational opportunities.

As magnifying glasses of wider societal issues, school settings offer an interesting entry point into a deeper understanding of the ways the contradictory policies, practices and discourses regarding unaccompanied refugee youth as 'crisis figures' (Lems, Oester and Strasser 2019) are lived and grappled with on the ground. For while schools are commonly perceived as places of future-making, they also represent the state's attempt at creating 'ideal' citizens. This is particularly visible in the schooling of immigrant and refugee youth, where the dividing line between inclusionary language and exclusionary practice becomes increasingly blurred (Abu El-Haj 2015; Gilliam and Gullov 2016; Jaffe-Walter 2016). I will suggest the importance of understanding the ways this logic of 'inclusive exclusion' (Oester and Lems, in press) seeps into young people's everyday lives and has the power to delineate their educational possibilities. I agree with the growing body of research on unaccompanied refugee youth that has pointed out the crucial potential of education in creating pathways into society (e.g. Chase and Statham 2013; Connolly 2015; Bitzi and Landolt 2017). However, by taking my cue from scholars that have shown the exclusionary dynamics underwriting many contemporary educational systems (e.g. Slee 2011; Abu El-Haj 2015) as well as the Janus-faced social realities that are the outcome of discourses and practices of integration' (e.g. Vertovec and Wessendorf 2010; Anthias 2013; Piñeiro 2015), I will shed light on the extremely contradictory expectations young unaccompanied refugees are confronted with in school settings. Based on insights from seventeen months of indepth ethnographic fieldwork with refugee youth in and beyond two integration classes in Bern, Switzerland, I will suggest that the ambiguous treatment of unaccompanied minors as vulnerable victims in need of protection and integration on the one hand and as threats to the economic and cultural integrity of the Swiss 'national order of things' (Malkki 1995) on the other, produces paradoxical dynamics whereby young people find themselves left outside whilst seemingly being 'in'.

As the emergence of the unaccompanied minor as a crisis figure plays a crucial role for understanding Swiss educational and policy responses and for the ascriptions young people have to deal with, I will first take some time to think through the divergent and often times conflicting expectations and ideas that become attached to this figure. In embedding the deeply ingrained ambiguity of the unaccompanied minor in political and social processes, I will argue that the logic of inclusive exclusion inherent in policy responses needs to be read against the backdrop of wider dynamics underwriting contemporary asylum policies in Europe that constantly swing back and forth between public moral outbursts of compassion and repressive countermoves (Fassin 2005; Lems, Oester, and Strasser 2019). By shedding light on the educational project where I conducted my research, I will show that the form of exclusion that is the outcome of these dynamics takes on an ambivalent shape: Whilst relying on inclusionary language and ideas, it reproduces distinct practices of social segregation. 


\section{From vulnerable victims to risky subjects}

One key focus of the growing body of literature on unaccompanied refugee youth has been the ambiguity and contradiction permeating this discursive figure. Researchers from different parts of the world have shown that the increased arrival of young unaccompanied refugees has provoked paranoid reactions by policymakers and the wider public that quickly shift back and forth from labelling them as 'at risk' to 'the risk' (Wernesjö 2019; Malkki 2010, 63; Bryan and Denov 2011, 244; Heidbrink 2014, 48). Most Western states, including Switzerland, pride themselves on adhering to the UN Convention on the Rights of the Child and have recognised unaccompanied minor asylum seekers as a particularly vulnerable refugee category in need of special protection and care. As a result, young people arriving in Switzerland as underage asylum seekers receive preferential treatment in terms of housing, supervision, access to education and the asylum procedure. The sense of vulnerability surrounding the figure of the unaccompanied minor could thus be seen to work as a protective shield against the threat of deportation and gives the young people the right to gain access to special treatment. Yet, a plethora of research on unaccompanied refugee youth from recent years shows that the moral conceptualisation of childhood underlying these policies acts like a double-edged sword: While it sets out to protect the rights of children, it also leads to institutionalised expectations about what determines the 'proper' refugee child (e.g. Eastmond and Ascher 2011; O'Higgins 2012; Ní Raghallaigh 2014; Connolly 2015; De Graeve 2017). These expectations are based on specific Western ideas of childhood that frame it as a time of innocence and vulnerability (Malkki 2010) and create a sharp division between childhood and adulthood (Pupavac 2001). Given the growing number of age dispute claims and age assessments concerning underage asylum seekers in the European Union, the question of who is and is not regarded to be a 'real' child quickly turns into a moral and political battleground (Bhabha 2007; Crawley 2007; Kvittingen 2010).

The flipside of morally charged discourses on childhood, then, is the vilification of those who subvert these categories. Hess and Shandy $(2008,767)$ compare the way the state deals with young refugees to a pendulum that keeps swinging back and forth between the urge to protect the most vulnerable members of society, and treating them as risks in need of discipline, policing or expulsion. In his groundbreaking work on the moral economy of immigration policies in Europe, Fassin (2005) has described this movement as one between compassion and repression. He argues that within an increasingly restrictive asylum landscape, acts of compassion towards refugees only appear as 'privileged moments of collective redemption' directed at individual cases labelled humanitarian exceptions (Fassin 2005, 375). These exceptional cases are deemed deserving the (often temporary) protection of European states based on humanitarian reasons, such as incurable illnesses or psychopathology, rather than their political biographies. While by virtue of their perceived extreme vulnerability unaccompanied minors can be said to form the 'perfect victims' (Ticktin 2016, 257), the status of exceptionality this affords them comes at a great cost. As Ticktin $(2016,258)$ points out, expecting unaccompanied minors to display innocence does not just depoliticise their stories. It also provokes a backlash against those who do not act according to these morally charged expectations and are subsequently penalised, silenced and excluded. Responses to unaccompanied minors that are based on compassion and exceptionality provoke what Ticktin $(2011,5)$ has so 
poignantly described as 'armed love', a form of engagement 'in which the moral imperative to act is accompanied, explicitly or implicitly, by practices of violence and containment'.

Similar dynamics can be seen in the treatment of unaccompanied refugee youth in Switzerland. Until recently the broader public was not aware of unaccompanied minors seeking asylum. From the summer of 2014 this changed dramatically. During these months the numbers of unaccompanied young people lodging asylum applications in Switzerland doubled from 346 in the year 2013 to almost 800 in 2014. In 2015 this number even quadrupled to close to 2800 (SEM 2016). Whereas until the summer of 2014 the media and broader public tended not to differentiate between various categories of asylum seeking youth, over the last years the clearly distinct figure of the unaccompanied child asylum seeker has entered the scene. It is a figure that is identified through specific attributes, such as vulnerability, lostness and need for protection and is imbued with specific rights. Compared to the suspicion that accompanies the reception of adult asylum seekers, the figure of the unaccompanied refugee child initially received a more positive public response in Switzerland. Throughout the summer months of 2015, when the country perceived itself to be in the midst of a 'refugee crisis', the home for unaccompanied minors where I conducted my fieldwork was faced with a wave of compassion by locals who, whilst often extremely suspicious of adult (particularly black, Muslim and male) asylum seekers, were deeply moved by the media stories of the unaccompanied minors who had survived harrowing journeys on their own. The home got inundated with clothes donations and volunteering bids to the point that the responsible organisation had to install a position dedicated solely to managing the help offers from the public. During this period, the predominantly Eritrean and Afghan unaccompanied minors arriving in Switzerland received refugee status or humanitarian protection across the board. Yet, just as the good-will of the masses welcoming the Syrian refugees arriving in German and Austrian train stations in the summer months of 2015 quickly turned into a deep-seated racialised fear of being outnumbered in one's own country (Hage 2016), so the narrative of the innocent unaccompanied refugee child morphed into one of the dangerous youth.

\section{Armed love in Switzerland}

Just how ambiguous the unaccompanied minor as a crisis figure is has become visible in recent developments in the Canton of Bern. Between May 2015 and November 2016, when I conducted my fieldwork, Bern was presented as a best practice example, as it had taken its obligation under the UN children's rights convention to guarantee special protection to unaccompanied minors seriously and invested in the establishment of child-appropriate accommodation and supervision infrastructure. While the opening of several new homes to accommodate the over five hundred unaccompanied refugee youth who had been allocated to the Canton of Bern throughout the turbulent summer months of 2015 was met by a general sense of approval, this sentiment swung around in May 2017, when the right-wing populist SVP party won a referendum that aimed to stop the funding of what they suggested to be a 'luxury' treatment of unaccompanied minors. Throughout the debates surrounding this event, the populist discourse subsequently casted doubt on the genuineness of the young people's claim of being under eighteen or 'real' refugees, instead introducing a narrative of their parents as irresponsible and calculating villains whose attempts at sending off their kids in order to live as parasites off the Swiss social 
system, should not be rewarded. In the context of the UK debate, Silverman (2016) has described this as the emergence of the 'imposter child', an increasingly accepted narrative that accuses child asylum seekers of faking their age and identity to gain access to the welfare system. Just how powerful such debates are is shown in the example of Bern, where the right-wing success in the popular vote against the special treatment of unaccompanied minors has subsequently led to debates about their deportability. The SVP's longstanding attempts to dismantle Eritrean asylum seekers' credibility through 'fact finding' trips to Eritrea and public campaigns such as the Bern referendum ultimately succeeded in initiating a policy change regarding the asylum cases of Eritrean unaccompanied minors. While most young Eritreans flee the country in fear of enforced conscription which usually starts at the age of sixteen, since late 2016 Swiss migration authorities explicitly only regard Eritreans who can proof that they were actively involved in the army or regime worthy of protection. This new policy has led to a wave of rejections of asylum applications by Eritrean unaccompanied minors in Switzerland. Crawley and Skleparis $(2017,4)$ point out that while the category of the refugee is a legal one that is shaped by the Refugee Convention, its interpretation and application is inextricably linked to specific national interests and priorities. These priorities constantly change, thereby also shifting who is regarded deserving refugee protection and who not. In these highly contentious debates unaccompanied minors find themselves thrown between two extreme poles: As their depiction as brutally calculating intruders to Switzerland's hard-earned wealth is gaining momentum, NGOs and those sympathetic to the plight of unaccompanied minors strengthen the narrative of them as helpless victims and children in need of protection.

\section{Crisis talk}

The emergence of the unaccompanied minor as a distinct crisis category cannot be separated from the dynamics of what I would describe as 'crisis talk'. The arrival of unprecedented numbers of refugees in Europe throughout the summer of 2015 provoked a politics of crisis. Within these dynamics, refugee crisis talk quickly degenerated into a means of justifying harsh, extremely exclusionary responses (Holmes and Castañeda 2016; Crawley and Skleparis 2017). In Switzerland, the sense of crisis surrounding the figure of the unaccompanied minor also needs to be read against the backdrop of a historically ingrained tradition of crisis talk in relation to migration. In this vein, Wicker (2009, 26) warns not to be deceived by the increased use of the positive language of 'integration' in relation to migrants and refugees since the turn of the millennium. He argues that current migration policies show an astonishing continuity with former approaches to migration, which were marked by extremely exclusionary practices. One key component is a deep-seated fear of Überfremdung (over-foreignisation). In Switzerland, this fear has a long history and has been present in migration policies from the nineteenth century onwards (Wicker 2009, 26). Building on this historically engrained narrative of Überfremdung the right-wing populist SVP party has been extremely successful since the early 2000 s in designing anti-immigration campaigns that continuously nourish a sense that the country is facing a migration crisis (D'Amato 2012, 99). I suggest that the emergence of the figure of the unaccompanied minor needs to be read within these national and transnational politics of crisis talk. It was born out of an on-going project of distinction between those who are classified as deserving protection (the especially vulnerable, such as single 
women, children, the chronically ill) and those who don't (such as single men, 'economic' migrants) and links into contradictory policies of 'integration', which are increasingly used against those who are deemed too culturally 'other' to be included.

Given the increasingly repressive nature of the European asylum system and the focus on isolated humanitarian exceptions this has provoked, the sense of ambiguity surrounding the figure of the unaccompanied minor should not come as a surprise. Rather, it suggests that the rhetoric of the vulnerability of the unaccompanied minor used by European governments needs to be read against the backdrop of wider societal dynamics that create temporally limited compassionate exceptions amidst a system based on containment, expulsion and control. De Graeve $(2017,81)$ describes the paranoid back and forth between inclusion and exclusion marking the response to unaccompanied minor asylum seekers as a 'policy of two rhythms'. She coined the term to depict the deeply indecisive nature of current policy approaches to unaccompanied refugee youth in Europe that are not sure "whether to stimulate their integration into host society or keep them apart for a swift return, wrapped in a language of the minor's "best interest" and a rhetoric of equal treatment, equal rights and standardization' (De Graeve 2017, 85). As I turn to my ethnographic fieldwork in an integration class for unaccompanied minors in Bern I will show that these developments cannot be reduced to the discursive level alone. Rather, the ambiguous back and forth between integration and banishment, innocence and guilt, compassion and repression inherent in the discursive construction of the figure of the unaccompanied minor trickles down into everyday interactions in school settings. I will show how within these deeply contradictory dynamics it becomes perfectly acceptable to implement the harshest measures of exclusion whilst cloaking them in a language of compassion and inclusion. Yet, the young refugees do not passively accept these dynamics. By looking into the everyday interactions between teachers and refugee students I will highlight the often small, intangible strategies young people deploy to voice critique over their continued social isolation.

\section{Methodological approach}

I started my fieldwork in June 2015, in a home for unaccompanied minors in a small mountain village about an hour's drive away from the city of Bern. ${ }^{1}$ At the time, this was the larger of two homes the cantonal authorities had opened for unaccompanied young asylum seekers, accommodating about sixty youth from different countries, with Eritreans forming the majority. I received access to the home under the pre-condition that I would find ways of making myself useful so that I would not disturb the daily routine in the home or become a nuisance to the social workers. I became involved in a radio project the home's pedagogical leader had initiated half a year before as a way of getting the young people to practice their German and voice concerns that were of importance to them. A fluctuating group of five to fifteen unaccompanied minors met once a week to work on short stories that were aired on an independent youth radio station in a monthly slot.

The radio project formed an important entry point into the lifeworlds of the eight young people from Eritrea, Guinea and Somalia who became my key participants. As I explain in more detail in the methods chapter of this special issue (Chase and Otto 2019), it formed a crucial vehicle for creating the space for experiences to become shareable. Through the weekly gatherings we got to know each other's biographies, hopes and despairs, and over time the young people were able to place me and my research. Once 
they had acquainted themselves with the idea that I was going to write 'a book' about them, as they liked to think about my research project, I extended our meetings beyond the radio setting and joined them in their everyday routes and routines. After gaining permission from the school, I also started participating in the reception classes for unaccompanied refugee youth all but one of the radio group's participants were attending. Over the course of half a year I alternately visited one of the two classes for unaccompanied minors in a bridging school for one day per week. Besides the two girls and six boys whose lifeworlds I focused on in detail, I met a further sixty unaccompanied refugee youth whose pathways I followed more loosely. Because of the insecure immigration status of many of the young people I worked with and the absence of an adult guardian, all names in this article have been changed. To protect the privacy of the teachers, I have also anonymised their names and the location of the school.

\section{Bridges to nowhere}

In the first few months, as we were getting to know each other while working on radio stories, the young people told me about the high hopes they held for the future. While Meron, an outspoken seventeen-year-old Eritrean was hoping to go to university to become a doctor, Thierno from Guinea dreamed of becoming a journalist. Jamila, a sixteen-year old girl from Eritrea was hoping to become a receptionist in a big hotel, while Abdi from the Somali minority in Ethiopia wanted to become a computer specialist - and so the list of dreams went on. Similar to Belloni's analysis of Eritrean youth's migratory pathways in this special issue, for almost all of my participants the urge to migrate was not solely driven by force. Rather, the young men and women I worked with also perceived migration and its promises of upward social mobility through education as a key stepping stone to reaching adulthood (see Belloni 2019). When I extended my research to the school setting, most of the young people had just made the move from the internal school in the home for unaccompanied minors to the so-called 'integration class', an educational structure that had been specifically set up to enhance their German skills and prepare them for an apprenticeship. In our weekly gatherings the participants in the radio project would often express their mixed feelings about the class. On the one hand they were glad to be given the opportunity to go to school. On the other hand they often signalled their eagerness to leave behind the integration class as quickly as possible, telling me that they hoped they would be able to join a 'normal' school soon. As time went by the future-projects they had told me about in our initial discussions receded further and further into the distance. While the hope for a good education had often propelled the young people during their dangerous journeys to Europe, they became increasingly aware of the difficulty of accessing these opportunities.

Unaccompanied minors in Switzerland are faced with many educational hurdles. In the first months after their arrival the young people I met went to the internal schools in the home for unaccompanied minors, where they learned German. After they had learned basic German, students under the age of sixteen were transferred to local schools and included in the Swiss mainstream school system. This, however, did not apply to any of my participants, as they were all older than sixteen. Because education is seen as an integration measure', which is only afforded to officially recognised refugees, the Swiss cantonal authorities often refuse to finance the schooling of asylum seeking youth and young people with temporary protection visas past the obligatory education cut-off age of 
sixteen. As the majority of the unaccompanied minors arriving in Switzerland are between sixteen and seventeen years old, many struggle to gain access to public education. What further complicates their situation is that the Swiss school system is marked by distinct practices of selection (Streckeisen, Hänzi, and Hungerbühler 2007). Swiss students are separated according to their skills from the early age of eleven to twelve to either get channelled into secondary schooling or an apprenticeship. Research has demonstrated that the earlier educational systems make these selections, the less permeable they become for learners who do not match the normalising expectations (Gomolla and Radtke 2007; Oester, Fiechter, and Kappus 2008).

In an attempt to create pathways into the apprenticeship stream some Cantons, including Bern, have opened so-called bridging schools (Brückenangebote) to unaccompanied minors over the age of sixteen. These schools were designed as interim solutions for students who have completed obligatory schooling and were neither able to secure an apprenticeship nor a placement in a secondary school. Under the guidance of specialised teachers and through work placements that allow them to gain experience in different trades they are expected to use the school as a bridge to transition into an apprenticeship. The two classes where I conducted my research were part of a larger educational pilot project in the Canton of Bern that used the available infrastructure of bridging schools for classes that were specifically aimed at preparing unaccompanied refugee youth for an apprenticeship. Unlike former education projects that had been solely open to youth with refugee status, this pilot project also enabled young people who were still awaiting the decision on their asylum application to gain access to education. Many of the refugee sector and educational practitioners I encountered in the field celebrated the Cantonal authorities' willingness to invest in young asylum seekers' integration as an important step forward. Yet, the young people attending these classes were less enthusiastic about the opportunities these classes opened up to them. In our weekly meetings they increasingly came to depict them as no through roads, as places that exacerbated their sense of otherness.

The young people's doubts are apparent in the following brief interaction, which occurred as the group was discussing their future plans. When the turn came to Meron, a very vocal young man who had been amongst the top-ranked students from his cohort in Eritrea, he told the group that he believed it was 'useless to attend a class with an I in front of it'. While he had been insistent about his dream of becoming a doctor in previous meetings - a dream he had been pursuing since his childhood and that had played an important role in his decision to leave Eritrea - within weeks of joining the integration class he came to perceive it as unattainable. At the school he went to and where I conducted my research, the two integration classes were marked with an 'I', thereby setting them off from the two regular classes (Regulärklassen) for Swiss students. When I asked Meron to explain why he believed that these classes were useless, his answer was clear:

'The "I" stands for one thing only: foreigners. When I am looking for an apprenticeship nobody is interested in someone like me, from a foreigner's class.

The conversation revealed the stigma the young people attached to the classes that were marked with an 'I'. Meron feared that the 'I' on his school report would haunt him forever as it revealed the fact that he was not going to a 'normal' school. Despite many active attempts to find information about the possibility of switching from the integration 
class to secondary schooling, his hopes had fallen on death ears with the teachers and social workers who routinely advised him to focus on securing an apprenticeship instead. In an attempt to adapt to these new parameters, Meron changed his plans of achieving a high school diploma to be able to attend university. Instead he started to invest all his energy into a new project: Receiving the head teacher's approval to make the transition from the integration class to one of the 'regular' classes within the bridging school. He hoped that a certificate that did not have an 'I' attached to it, would enable him to at least gain access to a full, four-year apprenticeship, rather than the lower qualified two-year apprenticeships the teachers were advising him and his classmates to apply for. In order to persuade his teacher, Meron switched his behaviour from a critically engaged student to a quiet and extremely well-organised pupil who put all his efforts into being able to 'read' and quickly react to his teachers' demands. Sometime later, when the conversation returned to the topic of their future plans, Meron said that he had resigned to the fact that he would have to take any apprenticeship he got offered. When I asked him what had happened to his plan of becoming a doctor, he responded:

To become a doctor you have to go to the very top. Look at me, I am at the bottom.

The sense of exclusion inherent in these conversations stood in stark contrast to the celebratory tone teachers and social workers used, who described the model of the integration class as a crucial step towards the young people's inclusion into Swiss society. In this vein, Mr. Müller, a teacher in one of the two integration classes I attended told me:

I would say that the vast majority of my work is not teaching German. It is integration work.

He strongly believed that by offering the young people the opportunity to learn about Swiss society and culture, he was helping them to find their feet in the educational landscape at large. While the teachers and practitioners kept talking about the integration classes in positive terms, framing them as bridges into Swiss society, the young people I worked with described them in much more ambiguous terms. As Meron's statements show, they increasingly came to question the premise of the idea of 'integration' the classes they attended were based on, which, they felt, did not entail the opportunity to become an equal part of society but rather their relegation to the lower ends of the social ladder. In order to understand the discrepancy between these intermingling narratives of inclusion and exclusion, I need to shed light on the ambiguous ways ideas about 'integration' and education entered the classroom.

\section{Integration work}

Upon joining the integration classes, the unaccompanied refugee youth were confronted with several levels of exclusion: Firstly, the structure of the bridging school itself can be described as a form of educational segregation as it is aimed at students who have fallen outside the mainstream schooling system. Swiss scholars have repeatedly critiqued these schools for their stigmatising tendencies, and particularly for directing working class and migrant youth into lower qualified educational and vocational tracks (e.g. Del Percio and Duchêne 2014; Schnell and Fibbi 2016). Secondly, within the bridging schools the refugee youth were taught in separate classes. This separation was not just educational, it was also physical: While the 'Swiss classes', as the young people described the 
mainstream bridging classes, were placed on the upper level of the building, the integration classes were at the bottom level, and there was hardly any interaction between them. Thirdly, there was a division between the two integration classes in beginners and advanced, which was extended by further segmentation within these classes as the teachers divided the students into groups according to their skills. Finally, there were varying degrees of social exclusion within these groups of young people. Depending on their age and visa status, some youth had a more stable footing in Switzerland giving them easier access to apprenticeships, while others were facing the threat of deportation. Similarly to the dynamics Hilt (2017, 593-94) observed in a reception class for newly arrived migrants in Norway, the many levels of exclusion in the integration classes created an informal 'map of limits' the students had to pass in order to be included in higher levels, with access to an apprenticeship forming the final goal. She points out that within this web of exclusions the path to inclusion is particularly difficult for the students at the lowest ranks, as they do not just have to work hard to make their way into mainstream education, but also overcome the internally produced barriers.

Despite these many levels of exclusion, the two teachers responsible for the integration classes did not see a contradiction between the aim of doing 'integration work' and the schooling of unaccompanied minors in segregated classes where they did not get to interact with Swiss peers. Both teachers were experienced pedagogues. Having spent many years teaching 'difficult' or marginalised students they perceived the work with unaccompanied minors to be an interesting challenge at the end of their careers. Both teachers were convinced that the separate stream of schooling in the integration classes was inevitable. They based the need for separate schooling on the grave deficiencies they believed the young people to have and that needed to be overcome before they could enter mainstream schools. When asked why, despite the fact that he was teaching the advanced class none of his students would enter mainstream secondary schooling in the next year, Mr Schmid responded:

It would be impossible to keep them there. Their German and educational levels are simply too low. I know this might be the kids' dream, but I strongly believe that the Swiss educational system should not bend for them. If we let them enter the regular school system, it will lower the educational standards for everyone.

Mr Schmid's response is telling for the general sense of deficiency the teachers attached to the unaccompanied minors. This was exacerbated by the perceived emotional shortcomings the teachers believed the youth to have due to their traumatic experiences. In creating the unaccompanied minor student as a figure riddled with problems the teachers homogenised the diversity in the educational backgrounds of the students attending their classes. While only a very small percentage had not received any prior schooling, and many had in fact very solid, if interrupted, educational biographies, the teachers tended to treat them all as if they had to start from scratch by teaching them what going to school actually entailed (also see Hilt 2016). Here, the young people's perceived educational and emotional deficiencies melded with a sense of cultural shortcomings. The teachers believed that because of their cultural backgrounds the refugee youth needed to be instructed on how to behave in the Swiss school system before they could be included in the mainstream. As a result, they put much emphasis on what they perceived to be particularly 'Swiss' values, such as punctuality and tidy appearance. In an attempt to get 
his students accustomed to Swiss school culture, Mr Schmid made a point of randomly inspecting students' folders for tidiness and order. He believed that this was a small, but important measure to lead the students towards a deeper cultural understanding of life in Switzerland. Like Mr Müller, he was convinced that their main task was to help the young people integrate into a system of values that, he believed, was deeply alien to them. In this vein, he said that it was 'very difficult, perhaps even impossible, for these kids to learn the Swiss democratic values'. Based on these perceived cultural and educational deficiencies, the teacher believed that it was impossible for his students to become part of a mainstream class anytime soon.

Despite these strong exclusionary undertones, it is important to note both teachers selfidentified as liberal, open-minded and concerned Swiss citizens who were critically opposed to dominant right-wing populist narratives about refugees. They saw their efforts to 'integrate' the young refugees as an important step towards more harmonious forms of cohabitation between migrants and Swiss citizens. The 'integration work' the teachers were performing on their students resembles the dynamics Jaffe-Walter $(2016,91)$ describes in her research on the interactions between teachers and Muslim migrant youth in Danish schools. She found that teachers often engaged in 'culture work' rather than focusing on academic work. Like the teachers in the Swiss integration classes, the Danish teachers did so because they believed assimilation to be a necessary precondition for academic success. The teachers in her research did not make use of openly racist ideas, instead cloaking their assimilationist ideas in liberal language of concern for their students. To describe this paradoxical movement between liberal concern and the compulsion for assimilation, Jaffe-Walter $(2016,2)$ coined the term 'coercive concern'. The Swiss teacher's integration work was driven by similar dynamics. Mirroring official integration discourses in Switzerland that constantly swing back and forth between a benevolent language of inclusion and the demand for assimilation (Piñeiro 2015), the teachers framed their urge to 'help' the unaccompanied minors integrate in benign expressions of care and concern for their futures. Yet, as I will show in a next step, this benevolence was very ambiguous and quickly shifted into a more demanding, accusatory tone.

\section{The logics of inclusive exclusion}

How fragile the line between the benevolent language of inclusion and the urge to banish and exclude difference is, becomes visible in a moment such as the following, which occurred on a Monday morning as Mr Schmid was discussing the students' progress in looking for work placements. When venting his frustration over their perceived lack of effort in sourcing a company willing to take them on, the teacher addressed the class:

With quite a few of you I have the feeling that you haven't made any progress. It's like you haven't moved forward at all since you arrived in Switzerland. It's like you don't want to learn anything, as if you are just sitting off your time here.

Tapping into a familiar Swiss narrative of refugees as lazy good-for-nothings who are just sitting off their time on the taxpayer's money, the teacher held the sense of stagnation their prolonged exclusion had created against the students. Rather than acknowledging the fact that many of the young people struggled to find apprenticeships because of structural discrimination in the labour market, their immigration status and the stigma attached to this 
'irregular' form of schooling, he searched the fault in the students themselves. In refusing to acknowledge their struggles as inextricably linked to wider socio-political questions, the teacher was able to hold them responsible for their own exclusion.

The students did not passively accept the teacher's hurtful remarks. Several of them protested, making attempts to explain the difficulties they encountered, including limited Internet access in the home for unaccompanied minors complicating the search for suitable companies, and the lack of businesses willing to take them on. Yet similarly to the expectations of gratitude described in Wernesjö's article in the context of Sweden (Wernesjö 2019), these discussions left the teacher even more infuriated by the absence of thankfulness the students displayed for the opportunity they had been given:

You are all coming to school out of your own free will. Some of you might think that this school is not the right thing for you, that it doesn't meet your expectations. Then you just have to leave the school and do something else.

Given the young refugees' lack of access to any other form of schooling, the teacher's suggestion that it was up to them to either accept their exclusion 'out of their own free will' or do something else was indeed insulting. It perfectly demonstrates the paradoxical dynamics inherent in the logic of inclusive exclusion: Whilst deploying positive, liberal vocabulary of free will and self-responsibility, it is used to justify a grammar of exclusion. Here, the figure of the unaccompanied minor joins the ranks of other groups of students marked as 'problem cases', which are subsequently made responsible for their own exclusion from mainstream schooling. Slee $(2011,144)$ suggests that the creation of an evergreater number of alternative provisions for students who do not fulfil normalised expectations needs to be read against the backdrop of neoliberal education reforms that have undermined efforts to create more inclusive school environments. Like the establishment of the integration classes, the justification of lower-tiered forms of schooling for pupils who are believed to 'contaminate' the educational opportunities of others does not rely on openly exclusionary language. Yet, the inclusionary language used in school settings should not deceive us into overlooking the continued existence of structural discrimination. The increased creation of separate tracks for students who are marked as deviations from the norm exemplifies the ways schools create segregation 'under a smokescreen of inclusive educational policy' (Slee 2011, 144).

The refugee youth were thus confronted with a number of mixed messages: While the teachers described them predominantly in terms of their deficiencies, arguing that they needed to become more 'integrated' in order to make the jump into mainstream education, they simultaneously faulted them for not being there yet. Although the schooling in separate classes that carried the stigma of 'integration' made the young people's efforts of getting to know Swiss peers impossible, the teachers scolded them for only sticking to themselves. And while the teachers wanted the refugee youth to show more self-initiative, they did not allow them to express any form of critique towards the mechanisms of segregation and discrimination they encountered in the Swiss system.

The tendency to disallow their inherently political struggles and biographies to enter the classroom was not passively accepted by the young people. Through small, seemingly banal gestures and actions aimed at disrupting the everyday routine in the classroom, they often found the means to force their teachers into a conversation. This becomes apparent in the following interaction that occurred in Mr Müller's German lesson. 
Shortly before the break the teacher wrote the words 'life/ I am alive' (Leben/ ich bin lebendig) onto the blackboard. To demonstrate the different ways the word 'life' can be used, he wrote down the sentence 'I love life' and asked students to come to the blackboard to add other sentences containing the word. Samuel, a seventeen years old Eritrean, raised his hand. He went to the blackboard and wrote down: 'I hate life'. This sentence was a clear message to the teacher. At this point in time, Samuel was extremely worried about his prospects of staying in Switzerland. As the Swiss government had recently changed its policy on the asylum applications of Eritrean unaccompanied minors and he had just turned eighteen and was thus no longer classified a vulnerable child, he was concerned about his future. Furthermore, he was frustrated with Mr Müller. While he had done his utmost to fit in the picture of the 'deserving', 'well-integrated' refugee by learning German and even securing an apprenticeship as a carpenter in record time, the teacher had been suspicious of his success. Several weeks before the incident on the blackboard, when Samuel had approached Mr Müller to tell him about the offer by a carpentry company, the teacher had reacted by questioning the truthfulness of his story, reminding him that with his status as an asylum seeker it was unlikely any business would offer him an apprenticeship.

The words Samuel wrote onto the blackboard can be seen as a direct expression of the worries and frustrations that had built up inside of him. Rather than allowing Samuel to express his anger over this futile situation, however, the teacher reacted by telling him that if he was not content with his life he himself needed to change. This led to a discussion in which the teacher made Samuel list the things he needed to do to improve his life, like becoming better at school, improving his German and completing an apprenticeship. Discussing the situation in a recorded interview session later on, Mr Müller said that he believed this sentence clearly demonstrated the urgent need for the student to take over more self-responsibility. 'He needs to see where he wants to go, needs to know what it is he needs to do and that he is doing it for himself, right?' By decoupling Samuel's statement from the context of a rigid asylum system that creates deeply rooted existential anxieties in the people subject to its force, the teacher again looked for the fault in the student himself. By holding the liberal ideal of self-responsibility against Samuel's critique, he effectively took the wind out of his sails. Not dissimilar to Thierno's statement in the opening sentence of the article that becoming 'integrated' meant accepting his role as an outsider in Swiss society, Mr Müller's response communicated that it was up to Samuel to learn how to live with exclusionary mechanisms rather than fighting them. As Samuel's confrontation with the teacher shows, however, the young people did not passively succumb to this situation. Within the realms of possibility, they actively challenged their teachers and voiced critique over their prolonged social and educational isolation.

\section{Conclusion}

The interactions between teachers and refugee youth presented in this article show the extremely contradictory ascriptions, policies and practices asylum seekers labelled as 'unaccompanied minors' have to deal with on an intimate, everyday level. On the one hand they are described as the most vulnerable members of society in need of special care and protection, giving them access to educational opportunities that are closed to other asylum seekers. Yet these 'integration' measures turn out to form everything but 
an easy pathway into Swiss society. Riddled with contradictory expectations that constantly swing back and forth between signalling refugee youth's right to inclusion and expecting them to wilfully accept their continued exclusion, the integration classes create a peculiar status of being allowed in, yet simultaneously kept out. These conflicting ideas do not just play out in media and policy discourses, but trickle down into everyday interactions and have the power to determine young people's educational opportunities to a great degree. At the same time the feeling of being 'inside out' produced on the intimate, small scale of the classroom needs to be read against the backdrop of wider social and political developments that deploy a positive language of inclusion to justify repressive, exclusionary practices.

Additionally to these complex social landscapes, many of the unaccompanied refugee youth I encountered throughout my research were experiencing a deep fear of turning eighteen and losing their status as humanitarian exemptions. Some of them, including Thierno, the young Guinean I introduced in the opening sequence, were all too aware that the minute they reached the legal age of majority, they would join the ranks of the 'undesirable' and thus deportable refugees. In an attempt to explain how difficult it becomes to imagine a future in such highly precarious circumstances, he explained:

People like me never have the time to learn how to swim. We get thrown into the ocean, and if we want to survive we cannot but swim, otherwise we will drown immediately.

His statement perfectly illustrates the painful ways the logics of inclusive exclusion enters into unaccompanied refugee youth's everyday lives. As Thierno points out, people like him have to be extremely agentive and resourceful to 'learn how to swim' in an environment that constantly changes. While he is attempting to get a sounding from the world around him, this world constantly spits back mixed signals, ranging from his right to become a part of society to the need to control, expel and banish him. Here the dark underbelly of the politics of inclusive exclusion becomes painfully apparent: While driven by a morally charged compulsion to help those deemed especially deserving, this deservingness is built on such unstable grounds that it vanishes as quickly as it appeared.

\section{Note}

1. My research was part of the project 'Transnational Biographies of Education' funded by the Swiss National Science Foundation that compared the educational pathways of unaccompanied minors in Switzerland and Turkey. The project was led by Sabine Strasser and Kathrin Oester. While I was responsible for the research in Switzerland, Eda Elif Tibet conducted research in Turkey.

\section{Acknowledgements}

This work was supported by the Swiss National Science Foundation under Grant 10001A_156476. I would like to express my thanks to Sabine Strasser and Kathrin Oester for discussing earlier versions of this article and to the two anonymous reviewers for their careful reading and helpful suggestions.

\section{Disclosure statement}

No potential conflict of interest was reported by the author. 


\section{Funding}

This work was supported by the Swiss National Science Foundation under Grant 10001A_156476.

\section{References}

Abu El-Haj, Thea Renda. 2015. Unsettled Belonging: Educating Palestinian American Youth after 9/ 11. Chicago: University of Chicago Press.

Anthias, Floya. 2013. "Moving Beyond the Janus Face of Integration and Diversity Discourses: Towards an Intersectional Framing." The Sociological Review 61 (2): 323-343.

Belloni, Milena. 2019. "Family Project or Individual Choice? Exploring Agency in Young Eritreans' Migration." Journal of Ethnic and Migration Studies. doi:10.1080/1369183X.2019.1584698.

Bhabha, Jacqueline. 2007. Seeking Asylum Alone - A Comparative Study: Unaccompanied and Separated Children and Refugee Protection in Australia, the UK and the US. Alexandria, NSW: Themis Press.

Bitzi, Barbara, and Sara Landolt. 2017. "Unaccompanied Minor Asylum Seekers: Processes of Subject Formation and Feelings of Belonging in the Context of Educational Experiences in Switzerland." Geographica Helvetica 72 (2): 217-226.

Bryan, Catherine, and Myriam Denov. 2011. "Separated Refugee Children in Canada: The Construction of Risk Identity." Journal of Immigrant \& Refugee Studies 9 (3): 242-266.

Chase, Elaine, Laura Otto, Milena Belloni, Annika Lems and Ulrika Wernesjö. 2019. "Methodological Innovations, Reflections and Dilemmas: The Hidden Sides of Research with Migrant Young People Classified as Unaccompanied Minors." Journal of Ethnic and Migration Studies. doi:10.1080/1369183X.2019.1584705.

Chase, Elaine, and June Statham. 2013. "Families Left Behind: Stories of Unaccompanied Young People Seeking Asylum in the UK." In Family Troubles? Exploring Changes and Challenges in the Family Lives of Children and Young People, edited by J. McCarthy, C. A. Hooper, and V. Gillies, 223-233. Bristol: Policy Press.

Connolly, Helen. 2015. "Seeing the Relationship Between the UNCRC and the Asylum System Through the Eyes of Unaccompanied Asylum Seeking Children and Young People." The International Journal of Children's Rights 23 (1): 52-77.

Crawley, Heaven. 2007. When is a Child Not a Child? Asylum, Age Disputes and the Process of Age Assessment. London: Immigration Law Practitioners' Association (ILPA).

Crawley, Heaven, and Dimitris Skleparis. 2017. "Refugees, Migrants, Neither, Both: Categorical Fetishism and the Politics of Bounding in Europe's 'Migration Crisis'." Journal of Ethnic and Migration Studies, 1-17. doi:10.1080/1369183X.2017.1348224.

D’Amato, Gianni. 2012. “Jenseits der Integrationspolitik als politisches Ritual?” In Alltag und Ritual: Staatsübergänge und Ritualisierungen in sozialen und politischen Feldern. Festschrift zu Ehren von Hans-Rudolf Wicker, edited by Judith Hangartner, Ueli Hostettler, Anja Sieber Egger, and Angelica Wehrli, 87-105. Zürich: Seismo.

De Graeve, Katrien. 2017. "Classed Landscapes of Care and Belonging: Guardianships of Unaccompanied Minors.” Journal of Refugee Studies 30 (1): 71-88.

Del Percio, Alfonso, and Alexandre Duchêne. 2014. "Sprache und sozialer Ausschluss: Eine Genealogie des schulischen Berufsintegrationsprozesses jugendlicher MigrantInnen in der Schweiz." In Mehrsprachigkeit und (Un-)Gesagtes, edited by Anna Schnitzer, and Rebecca Mörgen, 194-216. Basel: Beltz.

Eastmond, Marita, and Henry Ascher. 2011. "In the Best Interest of the Child? The Politics of Vulnerability and Negotiations for Asylum in Sweden." Journal of Ethnic and Migration Studies 37 (8): 1185-1200.

Fassin, Didier. 2005. "Compassion and Repression: The Moral Economy of Immigration Policies in France.” Cultural Anthropology 20 (3): 362-387.

Gilliam, Laura, and Eva Gullov. 2016. Children of the Welfare State: Civilising Practices in Schools, Childcare and Families. London: Pluto. 
Gomolla, Mechthild, and Frank-Olaf Radtke. 2007. Institutionelle Diskriminierung: Die Herstellung ethnischer Differenz in der Schule. Wiesbaden: VS Verlag.

Hage, Ghassan. 2016. “État de Siège: A Dying Domesticating Colonialism?” American Ethnologist 43 (1): 38-49.

Heidbrink, Lauren. 2014. Migrant Youth, Transnational Families, and the State: Care and Contested Interests. Philadelphia: University of Pennsylvania Press.

Hess, Julia Meredith, and Dianna Shandy. 2008. "Kids at the Crossroads: Global Childhood and the State (Special Issue).” Anthropological Quarterly 81 (4): 765-776.

Hilt, Line Torbjørnsen. 2016. “They Don't Know What It Means to Be a Student': Inclusion and Exclusion in the Nexus Between 'Global' and 'Local'." Policy Futures in Education 14 (6): 666-686.

Hilt, Line Torbjørnsen. 2017. "Education Without a Shared Language: Dynamics of Inclusion and Exclusion in Norwegian Introductory Classes for Newly Arrived Minority Language Students.” International Journal of Inclusive Education 21 (6): 585-601.

Holmes, Seth M., and Heide Castañeda. 2016. "Representing the 'European Refugee Crisis' in Germany and Beyond." American Ethnologist 43 (1): 12-24.

Jaffe-Walter, Reva. 2016. Coercive Concern: Nationalism, Liberalism, and the Schooling of Muslim Youth. Stanford: Stanford University Press.

Kvittingen, Anna. 2010. “Negotiating Childhood: Age Assessment in the UK Asylum System.” In Refugee Studies Centre Working Papers Series, 1-59. Oxford: Refugee Studies Centre.

Lems, Annika, Kathrin Oester, and Sabine Strasser. 2019. "Children of the Crisis: Ethnographic Perspectives on Unaccompanied Refugee Youth in and En Route to Europe." Journal of Ethnic and Migration Studies. doi:10.1080/1369183X.2019.1584697.

Malkki, Liisa. 1995. "Refugees and Exile: From 'Refugee Studies' to the National Order of Things." Annual Review in Anthropology 24: 494-523.

Malkki, Liisa. 2010. "Children, Humanity, and the Infantilization of Peace." In In the Name of Humanity, edited by Ilana Feldman, and Miriam Ticktin, 58-85. Durham: Duke University Press.

Ní Raghallaigh, Muireann. 2014. “The Causes of Mistrust Amongst Asylum Seekers and Refugees: Insights from Research with Unaccompanied Asylum-Seeking Minors Living in the Republic of Ireland." Journal of Refugee Studies 27 (1): 82-100.

Oester, Kathrin, Ursula Fiechter, and Elke-Nicole Kappus. 2008. Schulen in transnationalen Lebenswelten: Integrations- und Segregationsprozesse am Beispiel von Bern West. Zürich: Seismo.

Oester, Kathrin, and Annika Lems. In Press. "Recht auf Bildung? Unbegleitete Minderjährige zwischen Inklusion und Exklusion." In Zwischen institutioneller Regulierung und Selbstbestimmung, edited by Judith Hangartner, Marianna Jäger, Melanie Kuhn, Anja Sieber Egger, and Gisela Unterweger. Wiesbaden: VS Springer.

O’Higgins, Aoife. 2012. "Vulnerability and Agency: Beyond an Irreconcilable Dichotomy for Social Service Providers Working with Young Refugees in the UK." New Directions for Child and Adolescent Development 2012 (136): 79-91.

Piñeiro, Esteban. 2015. Integration und Abwehr: Genealogie der schweizerischen Ausländerintegration. Zürich: Seismo.

Pupavac, Vanessa. 2001. "Misanthropy Without Borders: The International Children's Rights Regime.” Disasters 25 (2): 95-112.

Schnell, Philipp, and Rosita Fibbi. 2016. "Getting Ahead: Educational and Occupational Trajectories of the New Second-Generation in Switzerland." Journal of International Migration and Integration 17 (4): 1085-1107.

Silverman, S. J. 2016. "'Imposter-Children' in the UK Refugee Status Determination Process." Refuge 32 (3): 30-39.

Slee, Roger. 2011. The Irregular School: Exclusion, Schooling, and Inclusive Education. London; New York: Routledge.

Staatssekretariat, and Staatssekretariat für Migration (SEM). 2016. "Unbegleitete minderjährige asylsuchende in der Schweiz (UMA): Statistiken/ Vergleichstabelle." Retrieved online (access date: July 1 2018): https:/www.sem.admin.ch/dam/data/sem/publiservice/statistik/asylstatistik/ statistiken_uma/uma-2016-d.pdf 
Streckeisen, Ursula, Denis Hänzi, and Andrea Hungerbühler. 2007. Fördern und Auslesen: Deutungsmuster von Lehrpersonen zu einem beruflichen Dilemma. Wiesbaden: VS Verlag für Sozialwissenschaften.

Ticktin, Miriam. 2011. Casualties of Care: Immigration and the Politics of Humanitarianism in France. Berkeley: University of California Press.

Ticktin, Miriam. 2016. “Thinking Beyond Humanitarian Borders.” Social Research 83 (2): 255-271. Vertovec, Steven, and Susanne Wessendorf, eds. 2010. The Multiculturalism Backlash: European Discourses, Policies and Practices. London; New York: Routledge.

Wernesjö, Ulrika. 2019. "Across the Threshold: Negotations of Deservingness Among Unaccompanied Young Refuges in Sweden.” Journal of Ethnic and Migration Studies. doi:10. 1080/1369183X.2019.1584701.

Wicker, Hans-Rudolf. 2009. “Die neue schweizerische Integrationspolitik.” In Fördern und Fordern im Fokus: Leerstellen des schweizerischen Integrationsdiskurses, edited by Esteban Piñeiro, Isabelle Bopp, and Georg Kreis, 23-47. Zürich: Seismo. 